\title{
Effectiveness of Skill Competency Programme on Ashirwad Scheme among the Anganwadi Workers at Meerut, U.P
}

\author{
Naveena $\mathrm{J} \mathrm{H}^{1}$, Priya Sharma ${ }^{2}$ \\ ${ }^{1}$ (Asst. Professor, Community Health Nursing, Amity College of Nursing, Amity University, Haryana, India) \\ ${ }_{2}^{2}$ (Community Health Nursing, Panna Dhai Maa Subharti Nursing College, Meerut, SVSU, India)
}

\begin{abstract}
In order to offer better medical care to children suffering from chronic diseases, the authorities of National Rural Health Mission (NRHM) have mooted a proposal to set up District Early Intervention Centre (DEIC) in all districts of the state UP. Officials claimed that children with chronic diseases being detected during the health check up camps by medical teams under Ashirwad scheme of NRHM would be entitled to all sorts of medical facility including treatment diagnosis tests. The focal point for the delivery of integrated child development service is the Anganwadi worker within the village, assume the vital role with her close contact with the community and she act as a liaison between the village population and the government administration. The Anganwadi is the central figure in meeting the needs of the children. In this point of view an experimental study was conducted to assess the effectiveness of skill competency programme on Knowledge and practice of Anganwadi workers regarding ashirwad scheme in selected Anganwadi centers at Meerut. The research design was pre experimental one group pre test post test design. Non probability purposive sampling method was used for the selection of samples. The instrument for the data collection was a structured questionnaire and observational checklist. Results: The mean post-test level of Knowledge is significantly higher than the mean pre test Knowledge scores that is $41.75 \%$ pre test and $81.75 \%$ post test with paired " $t$ " $=18.427$ at $P=0.001$ significance. The mean post-test level of practice is significantly higher than the mean pre test practice scores that is $36.61 \%$ pre test and $78 \%$ post test with paired " $t=44.0$ at $P=0.001$ significance There was significant association between the findings of Knowledge and practice with demographic variables such as qualification and special training on ashirwad scheme estimated by chi-square $\left(\chi^{2}\right)$ test. The major findings indicated that Anganwadi workers had inadequate Knowledge in various aspects of ashirwad scheme and ineffective practice. Skill competency programme was found to be a very effective method of providing information regarding ashirwad scheme.
\end{abstract}

Keywords: Anganwadi workers, Ashirwad scheme, Effectiveness, Meerut, Skill competency programme.

\section{Introduction}

Around 23,607 out of 2,64,360 students of primary, junior high school, intermediate colleges and anganwadi centers are suffering from 4Ds -- birth defects, deficiency, disease and disability. This was revealed by the campaign undertaken under the Ashirwad scheme. In fact, Ashirwad scheme being run under National Rural Health Mission (NRHM) enabled health authority to identify sick children. Under the scheme, medical teams cover all selected primary $\backslash$ junior high school $\backslash$ high school and intermediate college twice a year and conduct health check up of each and every enrolled child. ${ }^{1}$

In order to offer better medical care to children suffering from chronic diseases, the authorities of National Rural Health Mission (NRHM) have mooted a proposal to set up District Early Intervention Centre (DEIC) in all districts of the state. These centres will have a team of specialist doctors and staff nurses and round the clock treatment will be offered. Officials claimed that children with chronic diseases being detected during the health check up camps by medical teams under Ashirwad scheme of NRHM would be entitled to all sorts of medical facility including treatment diagnosis tests. They would remain under doctors surveillance till they recover completely. ${ }^{2}$

Since most of the children go to Anganwadi center every day and minor ailments like diarrhea, dysentery, common cold, fever, rhinorrhea are more in children, it is responsibility of Anganwadi worker to know about the minor ailments of children In India each year 27 million children are born. Around $10 \%$ of them do not survive to 6 years of age .India contributes to $25 \%$ of the over 10.6 million under five death occurring world wide every year. In India about $30 \%$ of the babies are born with low birth weight, which are at high risk of morbidity and mortality. As per the 2006 census India has around 157.86 million children, constituting $15.42 \%$ of India's population who are the age of bellow 6 years. ${ }^{3}$

Mal-nutrition in India is associated with factors such as social, economic and moral aspects. The vulnerable period is 4 years of life only $40 \%$ of children of this age group consume adequate diet as seen from available data. "It has been estimated that there are now about 45 million undernourished children in our 
country. That they need an extra 300 calories per day" it is reported that $60-70 \%$ of young children today have nutritional deficiency. The incidence of severe cases is 1 to 2 percent in pre-school age children. ${ }^{3}$

According to latest UNICEF data, $47 \%$ of all under five children are underweight (moderate to severe) and $16 \%$ show moderate to severe wasting where as another $46 \%$ are moderate to severely stunted. The incidence of protein energy malnutrition in India among preschool children is one to two percent. Recent data from the WHO, had reported that about $60 \%$ of all deaths, occurring among children aged less than five years in developing countries, could be attributed to malnutrition. It has been estimated that nearly 50.6million under five children were malnourished and almost $90 \%$ of these children were from developing countries ${ }^{4}$.

A study was conducted in UP to evaluate the changes in knowledge of Anganwadi workers regarding growth monitoring through knowledge up-gradation training. It was a field based interventional study, which was conducted on 66 AWWs each from Chiraigaon (intervention) and Cholapur (control) blocks of Varanasi district. The primary tool in this study was a pre-designed and pretested interview schedule for collecting information ${ }^{\text {ee }}$ p pertaining to study objective. Results showed that the mean score of knowledge was around 19.7 (max. Score was 30) in both the blocks during baseline survey and almost all the AWWs were having either average or good knowledge of growth monitoring. Post intervention a significant $(\mathrm{p}<0.01)$ difference has been observed between the mean knowledge scores of AWWs in intervention (25.32 \pm 2.44$)$ and control $(20.35 \pm 2.70)$ blocks and as much as $48.5 \%$ of AWWs were having excellent knowledge about growth monitoring in Chiraigaon block. The knowledge up-gradation was found effective in improving the knowledge status of AWWs with regard to growth monitoring.

As the investigator observed that the Anganwadi Workers are not having adequate knowledge in performing their set functions especially with emphasize to growth, monitoring and supplementary nutrition. Also they are not following principles while checking growth monitoring and distribution of supplementary food. The investigator found that the Anganwadi worker not only identify the malnourished children but also children at risk for malnutrition through growth monitoring and supplementary feeding. Since these two activities takes major contribution in maintaining the health of the children, the investigator taken these two activities in the study in a limited time.

\section{Problem Statement}

A study to assess the effectiveness of skill competency programme about Ashirwad scheme among the Anganwadi workers in the selected Community at Meerut.

\section{Objectives of the Study}

To develop and validate skill competency programme regarding Ashirwad scheme among Anganwadi workers.

1. To assess the knowledge and practices of Anganwadi workers regarding Ashirwad scheme before and after administration of skill competency programme.

2. To evaluate the effectiveness of skill competency programme on Ashirwad scheme among Anganwadi worker in terms of knowledge and practice scores.

3. To determine the association of post test knowledge score and practice score with selected demographic variables

\section{Methodology}

The research approach adopted for this study was evaluative in nature. The target population of the study is made up of Anganwadi workers who are working in the Anganwadi centre of Meerut. A preexperimental single group pre-test post-test design was used to assess the effectiveness of Skill competency programme on the knowledge and practices of Anganwadi workers.. The sample consists of 30 Anganwadi workers of Meerut. In this study non probability purposive sampling technique was used for selection of samples. The instrument for the data collection was a structured questionnaire and had three parts: A: Sociodemographic data, B: Structured questionnaire to assess the knowledge level of the Anganwadi workers, C: Structured observation checklist to assess the practice aspect of selected samples. The data obtained was analyzed by using descriptive and inferential statistics in terms of frequency, percentage, mean, standard deviation, paired't' test and Chi-square test. The anonymity and confidentiality of the study subjects was maintained throughout the study. 


\section{Results}

A total of 30 Anganwadi workers working in the Anganwadi centre Meerut.

Table 1: Determination of Overall Mean Knowledge Score Before and after skill competency programme

\begin{tabular}{|l|l|l|l|lr|}
\hline AREA & $\begin{array}{l}\text { No. of the } \\
\text { Anganwadi workers }\end{array}$ & $\begin{array}{l}\text { Pre-test } \\
\text { Mean } \pm \text { SD }\end{array}$ & $\begin{array}{l}\text { Post-test } \\
\text { Mean } \pm \text { SD }\end{array}$ & Student paired t-test \\
\hline Overall Knowledge score & 30 & $16.07 \pm 3.35$ & $32.78 \pm 3.44$ & $\begin{array}{l}\text { t=18.427 } \\
\text { significant }\end{array}$ & P=0.05 \\
\hline
\end{tabular}

Table no 1 shows the comparison of overall Knowledge of Anganwadi workers before \& after Skill competency programme. On an average Anganwadi workers improved their Knowledge from 16.07to 32.78 after Skill competency programme or we can say, in pre-test they are able to answer only 16 questions before Skill competency programme, after Skill competency programme they are able to answer up to 32 questions, total questions were 40 . The difference between pre and post- test Knowledge score is $\mathrm{t}=18.427 \mathrm{P}=0.05$ significant and it was significant. Statistical significance was calculated by using student's paired ' $t$ ' test.

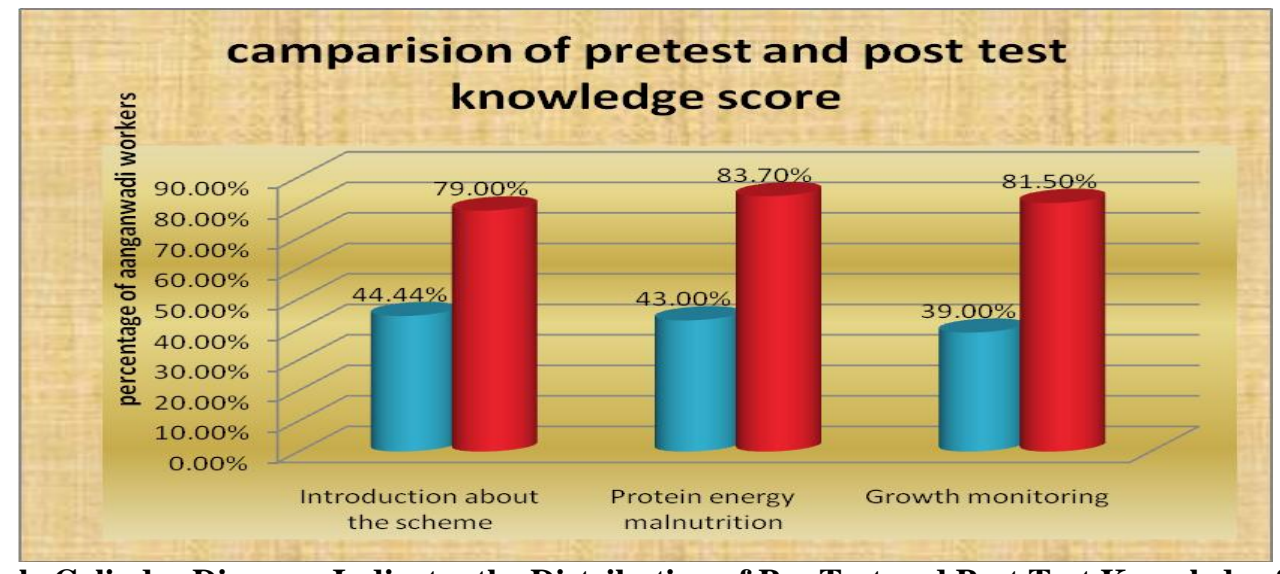

Multiple Cylinder Diagram Indicates the Distribution of Pre Test and Post Test Knowledge Scores

\section{Practice Gain after Skill Competency Programme}

\begin{tabular}{|l|l|l|l|}
\multicolumn{1}{l}{$\mathbf{N = 3 0}$} \\
\hline Practice assessment & $\%$ of Pre-test practice & $\%$ of Post-test practice & $\%$ of Practice gain \\
\hline Weight measurement & $47.5 \%$ & $88 \%$ & $40.5 \%$ \\
\hline Height measurement & $37.77 \%$ & $72.5 \%$ & $34.73 \%$ \\
\hline Growth monitoring & $33.33 \%$ & $80 \%$ & $46.67 \%$ \\
\hline Hand hygiene & $29.63 \%$ & $74 \%$ & $44.37 \%$ \\
\hline O.R.S prepration & $46 \%$ & $79.2 \%$ & $33.2 \%$ \\
\hline OVER ALL & $\mathbf{3 6 . 6 \%}$ & $\mathbf{7 8 \%}$ & $\mathbf{4 1 \%}$ \\
\hline
\end{tabular}

Table no 2 shows the comparison of practice gain on Ashirwad scheme before \& after Skill competency programme .In all the aspects, Anganwadi workers improved their practice after the administration of Skill competency programme. Over all $41 \%$ of practice gain is the net benefit of this study, which indicates the effectiveness of skill competency programme.

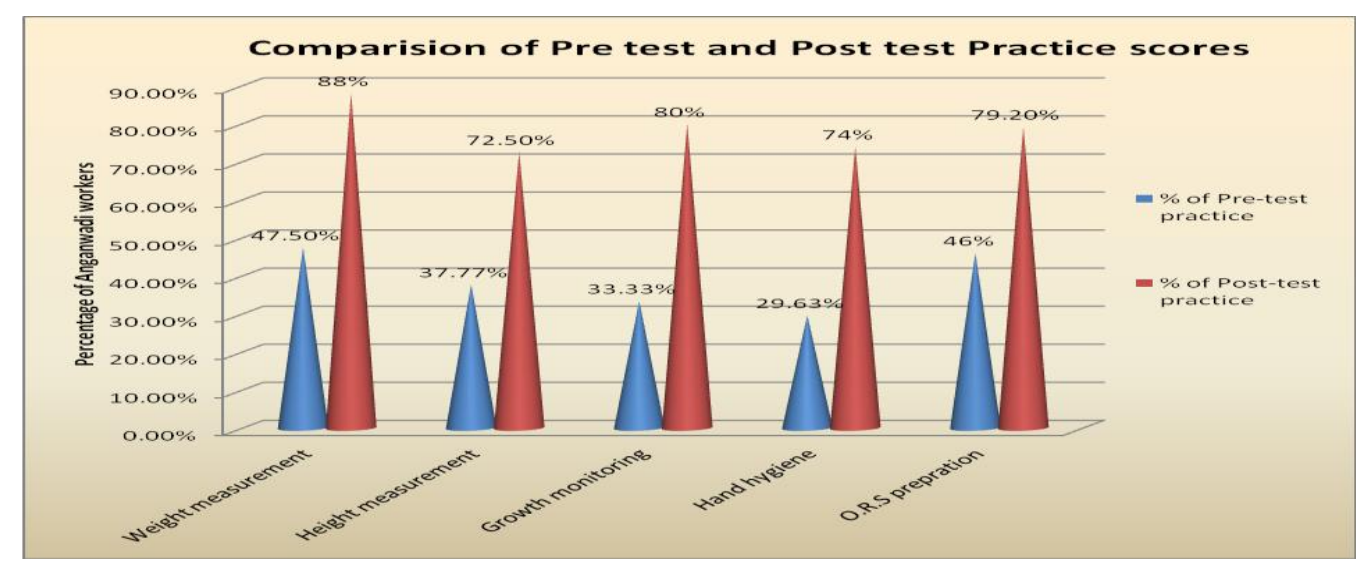

Multiple Cone Diagram Indicates the Distribution of Pre Test and Post Test Practice Scores 
Table 3: Association between Post-Test Level of Knowledge and their Demographic Variables

\begin{tabular}{|c|c|c|c|c|c|c|c|c|}
\hline \multirow{4}{*}{\multicolumn{2}{|c|}{ Demographic variables }} & \multirow{2}{*}{\multicolumn{2}{|c|}{ Moderate }} & \multirow{2}{*}{\multicolumn{2}{|c|}{ Adequate }} & \multirow[b]{4}{*}{ Total } & \multirow{4}{*}{$\begin{array}{l}\text { Table } \\
\text { value }\end{array}$} & \multirow[b]{4}{*}{ Chi square test } \\
\hline & & & & & & & & \\
\hline & & \multirow[t]{2}{*}{$\mathbf{N}$} & \multirow[t]{2}{*}{$\%$} & \multirow[t]{2}{*}{$\mathbf{N}$} & \multirow[t]{2}{*}{$\%$} & & & \\
\hline & & & & & & & & \\
\hline \multirow[t]{4}{*}{ Age in years } & $18-25$ & 4 & $44.44 \%$ & 5 & $55.55 \%$ & 9 & \multirow{3}{*}{$t=7.82$} & \multirow{4}{*}{$\begin{array}{l}\chi^{2}=0.08 \\
P=0.77 \\
\text { Not significant } \\
\text { df-3, }\end{array}$} \\
\hline & $26-33$ & 5 & $55.55 \%$ & 4 & $44.44 \%$ & 9 & & \\
\hline & $34-44$ & 7 & $63.63 \%$ & 4 & $36.36 \%$ & 11 & & \\
\hline & above 44 & 1 & $12.5 \%$ & 0 & $0 \%$ & 1 & & \\
\hline \multirow[t]{3}{*}{ Qualification } & $\begin{array}{l}\text { Higher } \\
\text { Secondary }\end{array}$ & 9 & $90 \%$ & 1 & $10 \%$ & 10 & \multirow{3}{*}{$\mathrm{t}=9.21$} & \multirow{3}{*}{$\begin{array}{l}\chi^{2}=11.81 P=0.05 \\
\text { Significant } \\
\text { df }-2,\end{array}$} \\
\hline & $\begin{array}{l}\text { Senior } \\
\text { Secondary }\end{array}$ & 4 & $50 \%$ & 4 & $50 \%$ & 8 & & \\
\hline & Graduate & 4 & $33.33 \%$ & 8 & $66.66 \%$ & 12 & & \\
\hline \multirow[b]{2}{*}{ Special training } & Yes & 14 & $58.3 \%$ & 10 & $41.60 \%$ & 24 & \multirow[b]{2}{*}{$\mathrm{T}=5.41$} & \multirow[b]{2}{*}{$\begin{array}{l}\chi 2=5.46 \mathrm{P}=0.02 \\
\text { Significant } \\
\text { df- } 1,\end{array}$} \\
\hline & No & 3 & $50.0 \%$ & 3 & $50.0 \%$ & 6 & & \\
\hline \multirow[t]{2}{*}{$\begin{array}{lll}\text { Mode } & \text { of } & \text { food } \\
\text { supply } & & \\
\end{array}$} & \begin{tabular}{|l|}
$\begin{array}{l}\text { Contract } \\
\text { based }\end{array}$ \\
\end{tabular} & 14 & $60.8 \%$ & 9 & $39.13 \%$ & 23 & & \multirow{2}{*}{$\begin{array}{l}\chi 2=0.57 \mathrm{P}=0.96 \\
\text { Not significant } \\
\text { df }-1,\end{array}$} \\
\hline & $\begin{array}{l}\text { Self } \\
\text { preparation }\end{array}$ & 3 & $42.8 \%$ & 4 & 57.14 & 7 & $\mathrm{~T}=3.80$ & \\
\hline
\end{tabular}

Table no 3 shows the association between socio-demographic variables and the post test knowledge scores of Anganwadi workers. Findings shows Anganwadi workers in post test have a significant association with Qualification $\chi 2=11.81 \quad(\mathrm{P}=0.05$ significance) and with special training $\chi 2=5.06(\mathrm{P}=0.02$ significance). These types of association are statistically significant and it was calculated using Pearson chi square test/Yates corrected chi square test.

Table 4: Association between Post-Test Level of practice and their Demographic Variables

\begin{tabular}{|c|c|c|c|c|c|c|c|c|}
\hline \multirow{4}{*}{ Demographic variable } & & & & & & & & $\mathrm{N}=30$ \\
\hline & & \multicolumn{2}{|c|}{ Moderate } & \multicolumn{2}{|c|}{ Adequate } & \multirow[b]{3}{*}{ Total } & \multirow{3}{*}{$\begin{array}{l}\text { Table } \\
\text { value }\end{array}$} & \multirow{3}{*}{$\begin{array}{l}\text { Pearson } \\
\text { chi square test }\end{array}$} \\
\hline & & \multirow[t]{2}{*}{$\mathbf{N}$} & \multirow[t]{2}{*}{$\%$} & \multirow[t]{2}{*}{$\mathbf{N}$} & \multirow[t]{2}{*}{$\%$} & & & \\
\hline & & & & & & & & \\
\hline \multirow[t]{6}{*}{ Age in years } & $18-25$ & 5 & $44.44 \%$ & 4 & $55.55 \%$ & 9 & \multirow{6}{*}{$\mathrm{T}=7.82$} & \multirow{6}{*}{$\begin{array}{l}\chi 2=0.49 \\
\mathrm{P}=0.48 \\
\mathrm{df}=3, \\
\text { Not significant }\end{array}$} \\
\hline & $26-33$ & 3 & $55.55 \%$ & 6 & $44.44 \%$ & 9 & & \\
\hline & $34-44$ & 7 & $63.63 \%$ & 4 & $36.36 \%$ & 11 & & \\
\hline & above 44 & 0 & $12.5 \%$ & 1 & $0 \%$ & 1 & & \\
\hline & Senior Secondary & 3 & $37.5 \%$ & 5 & $62.5 \%$ & 8 & & \\
\hline & Graduate & 7 & $58.33 \%$ & 5 & $41.66 \%$ & 12 & & \\
\hline \multirow[b]{2}{*}{ Special training } & Yes & 11 & $45.83 \%$ & 13 & $54.16 \%$ & 24 & \multirow[b]{2}{*}{$\mathrm{T}=3.84$} & \multirow[b]{2}{*}{$\begin{array}{l}\chi^{2}=4.10 \\
P=0.04 \mathrm{df}=1 \\
\text { Significant }\end{array}$} \\
\hline & No & 4 & $66.66 \%$ & 2 & $33.33 \%$ & 6 & & \\
\hline \multirow[t]{2}{*}{ Mode of food supply } & Contract based & 14 & $60.8 \%$ & 9 & $39.13 \%$ & 23 & \multirow[b]{2}{*}{$\mathrm{T}=2.71$} & \multirow{2}{*}{$\begin{array}{l}\chi_{2}^{2}=0.57 \\
P=0.96 \\
d f=1, \\
\text { Not significant }\end{array}$} \\
\hline & Self preparation & 3 & $42.8 \%$ & 4 & $57.14 \%$ & 7 & & \\
\hline
\end{tabular}

Table no 4 shows the association between socio-demographic variables and the post-test level of practice on Ashirwad scheme. Association with special training $\chi 2=4.10(\mathrm{P}=0.04$ Significance $)$ was significantly associated with their post-test practice score. This association was statistically significant and it was calculated using Pearson chi square test/Yates corrected chi square test

\section{Nursing Implication}

The findings of the study will help the investigator in the following ways:

$>$ Gaining the more knowledge regarding Ashirwad scheme.

$>$ Encourage the workers to improve their skills regarding Ashirwad scheme during working period.

NURSING EDUCATION: To improve the knowledge and practice of Anganwadi workers regarding Ashirwad scheme the nurse educator provide pre occupational training to all Anganwadi workers so, that they all will have adequate knowledge regarding Ashirwad scheme which will help them in their working place. There 
should be separate growth monitoring chart for all trainees in which they should assess and practice the level of malnutrition among the under five children. Therefore, nursing education is must for improving the Knowledge of the Anganwadi workers in the community. In the college of nursing the nurse educator also provide teaching to the A.N.M student so that they have adequate knowledge regarding Ashirwad scheme.

NURSING PRACTICE: For improving the practice of Anganwadi workers, there is a need for regular teaching programme which will improve their practice level which leads to timely intervention. To reduce the cases of under five malnutrition. To improve the skills of Anganwadi workers in service workshop should be organized at regular period so that their practice will be updated and refined.

NURSING ADMINISTRATION: As a administrative role of nurse will enhance the working capabilities of Anganwadi workers in the rural areas. The nurse administrators assess the quality of care provided by the Anganwadi workers regarding Ashirwad scheme. It will improve the quality assurance of Anganwadi workers in rendering care to the children at the Anganwadi center. This will minimize the confusion in assessing and classifying the children according to their specific sign and symptoms and increase the preparedness of Anganwadi workers in minimizing the malnutrition cases.

NURSING RESEARCH: The findings of the present study are helpful for the nursing professionals and nursing students to conduct further studies to find out the effectiveness of various methods of providing education on improving the Knowledge and practice regarding Ashirwad scheme among Anganwadi workers and public. It will in turn strengthen nursing research pertaining to the Community health nursing.

\section{Conclusion}

As the part of the study 30 Anganwadi workers were given the skill competency programme. The programme helps the Anganwadi workers to improve their knowledge and practice on Ashirwad scheme. This will ultimately helps to reduce the number of cases of malnutrition. The findings of the study indicate that there is improvement in knowledge and practice of Anganwadi workers which indicate that the skill competency programme is an effective in improving the knowledge and practices of the Anganwadi workers.

\section{Acknowledgements}

The authors sincerely acknowledge the support and guidance from Prof. Ex. Capt. Geeta Parwanda, Principal, Panna Dhai Maa Subharti nursing college, Meerut. Authors wish to extend sincere gratitude to all the Anganwadi workers of Meerut District for active participation in our study.

\section{References}

[1]. Kapil Dixit, 4Ds a major hurdle for kids' growth, The Times of India, Allahabad, Nov 13, 2013. Available From: http://timesofindia.indiatimes.com/city/allahabad/4Ds-a-major-hurdle-for-kids-growth/articleshow/25664025.cms

[2]. Kapil Dixit, NRHM to provide effective medical facilities to children, The Times of India, Allahabad, Jan10, 2014. Available From:http://timesofindia.indiatimes.com/city/allahabad/NRHM-to-provide-effective-medical-facilities-tochildren/articleshow/28632270.cms

[3]. Park. K. text book of preventive and social medicines $14^{\text {th }}$ ed., M/s Bansari Das Bhanot Publishers, Jabalpur.2008

[4]. Faruque AS, Ahmed AM, Ahmed T, Islam MM, Hossain MI, Roy SK, Alam N, Kabir I, Sack DA. Nutrition: basis for healthy children and mothers. J Health Popul Nutr. 2008 Sep;26(3):325-39.Available From: https://www.ncbi.nlm.nih.gov/ pubmed/18831228

[5]. Prabha C, Srivastava R K, Singh G P, Singh S P, Gupta M K. An intervention to improve the knowledge of anganwadi workers pertaining to growth monitoring in rural areas of Varanasi district, India. Int J Res Med Sci 2016;4: 2030-8.Available From: http://www.msjonline.org/index.php/ijrms/article/viewFile/857/828 